\title{
Toward an Assessment of Cultural Relativity and Impacts of ICT Interventions: Assessing ICT4D at the National Level
}

\author{
Kweku-Muata Osei-Bryson \\ Virginia Commonwealth University, USA \\ KMOsei@VCU.Edu
}

\author{
Lemuria Carter \\ Virginia Commonwealth University, USA \\ LDCarter@VCU.Edu
}

\begin{abstract}
Technological innovations have a momentous impact on society. Research has explored the role of culture and decision-making on IT development and diffusion. However, to-date, few studies have examined the role of ICT impacts and culture on IT decisionmaking in developing countries. In this conceptual paper, we integrate Hofstede's Cultural Dimensions and the Decision Style Inventory into ICT for Development security impact assessment frameworks. In particular, we use the proposed solution artifacts to assess the confidentiality, integrity and accessibility (CIA) security risks for a developing country. Implications for research and practice are discussed.
\end{abstract}

\section{Introduction}

According to a recent call for papers on cyber-security for development [1]:

Although the use of ICTs offer several potential benefits including improvements in efficiency \& reduction in costs, and wide-spread access to information and services, they also expose individuals, organizations \& nations to new risks including those that result from Internet-related security breaches and misuse of cyber-power. Inadequate understanding of the security implications of ICT acquisition, implementation, maintenance \& retirement decisions can lead to significant negative impacts on individuals, organizations, and nations. ... Thus there is the need for rigorous research that provides guidance to individuals, organization, planners and other government officials in developing countries, particularly those with limited financial, technical and other resources (p.1).

In this paper, we present framework artifacts for assessing the potential security impacts of ICT innovations \& interventions in developing countries.
These frameworks could be used determine if such innovations (e.g. cloud computing) are "good" option, and could be valuable in the context of some developing nations that may have limited knowledge and skilled personnel to effectively evaluate the advantages and challenges associated with technological innovations. We focus on the confidentiality, integrity and accessibility (CIA) dimensions of security risks; however, the proposed artifact can be used to explore diverse risks and impacts. Our initial motivation for this paper is based on concerns discussed briefly below regarding these security dimensions. Regarding confidentiality, a foreign organization that does not consider itself answerable to the National Government of a Developing country yet holds a mass of voluntarily provided data on personal details and relationships of citizens of the developing country presents an interesting challenge. Should this situation be a national security concern, particularly if the foreign organization has shown itself willing to share such data with its own government? Integrity impacts national security, information \& dis-Information. Faulty decision making may occur because of faulty information. Finally, availability is a critical issue for information communication technology for development (ICT4D) security. Is data/information that required to make decisions on development easily available to citizens, and the corporate \& political directorates of developing countries? 'Developed' countries have on numerous occasions frozen financial assets owned by other states. Since data is a strategic asset, in a cloud computing environment could data owned by organizations of a developing country be frozen the government of a 'developed' country?

In developing our ICT impact frameworks, we considered the concepts of: cultural dimensions (e.g. Hofstede (1983) [2]), Rowe \& Boulgarides (1987) [3, 4] Decision Style Inventory.

The proposed artifacts can be used to: 
- Identify confidentiality, integrity and accessibility (CIA) security risks for a developing country

- Present a risk assessment framework to aid managers in developing countries

- Provide a foundation for future research on the role of ICT4D impacts, cultural dimensions and decision making styles

It should be noted that although we focus our discussion on developing countries that the proposed artifacts can be used to assess both developed and developing nations.

\section{Conceptual Development}

\subsection{Cultural Dimensions}

According to Hofstede (1983), nationality is important to management for political, sociological, and psychological reasons [2]. He presents the following four cultural dimensions that have been studied extensively and expanded occasionally.

1. Individualism versus Collectivism

2. Large or Small Power Distance

3. Strong or Weak Uncertainty Avoidance

4. Masculinity versus Femininity

Individualism versus Collectivism refers to the way an induvial relates to others, either via loose or strong ties. Power Distance addresses how societies account for inequalities among individuals, either via emphasizing or minimizing the impact of differences in physical and intellectual capacities. Uncertainty avoidance refers to how individuals approach risk, either by embracing it or fearing it. Finally, Masculinity versus Femininity explores how societies define social gender roles. Some societies have strong delineations for expected and accepted male and female behaviors.

Given the prevalence of cultural dimensions and their impact on organizations, we explore the impact of these dimensions on decision styles.

\subsection{Decision Styles}

According to Rowe and Boulgarides (1983), decision making is impacted by "the context in which a decision is made, the decision maker's way of perceiving and understanding cues, and what the decision maker values or judges as important [3]." The Rowe \& Mason (1987) Decision Style Inventory (DSI) is a cognitive management tool used to ascertain the type of decisions an individual will probably make in a given situation [4]. Each individual has a distinctive method for making decisions; each approach has its own strengths and weaknesses. Understanding IT manager's likely behavior or decisions can help organizations engage in more strategic decisionmaking.

Table 1: Decision Styles' Characteristics Proposed by Rowe \& Mason (1987)

\begin{tabular}{|c|c|c|}
\hline & $\begin{array}{l}\text { High Tolerance } \\
\text { for Ambiguity } \\
\text { (Low Need for } \\
\text { Structure) }\end{array}$ & $\begin{array}{l}\text { Low } \\
\text { Tolerance for } \\
\text { Ambiguity } \\
\text { (High Need for } \\
\text { Structure) }\end{array}$ \\
\hline $\begin{array}{l}\text { Task } \\
\text { Oriented/ } \\
\text { Technical } \\
\text { Concerns }\end{array}$ & $\begin{array}{l}\text { Analytical } \\
\text { Solves problems } \\
\text { by analysis, } \\
\text { planning, and } \\
\text { forecasting }\end{array}$ & $\begin{array}{l}\text { Directive } \\
\text { Solves } \\
\text { problems by } \\
\text { applying } \\
\text { operational } \\
\text { objectives in a } \\
\text { systematic and } \\
\text { efficient way }\end{array}$ \\
\hline $\begin{array}{l}\text { People } \\
\text { Oriented/ } \\
\text { Social } \\
\text { Concerns }\end{array}$ & $\begin{array}{l}\text { Conceptual } \\
\text { Solves problems } \\
\text { by exploring } \\
\text { new options, } \\
\text { forming new } \\
\text { strategies, being } \\
\text { creative, and } \\
\text { taking risks }\end{array}$ & $\begin{array}{l}\text { Behavioral } \\
\text { Solves } \\
\text { problems } \\
\text { through people }\end{array}$ \\
\hline
\end{tabular}

Osei-Bryson and Barclay (2015) indicate the DSI has been applied in multiple contexts [5]. Nutt (1993) utilized the inventory to assess attitude toward ambiguity and uncertainty and to determine the decision style of executives [6]. Respondents evaluated the adoptability and risk of eight capital expansion projects and the researcher made inferences about decision-making based on these evaluations. The tolerance for ambiguity, uncertainty scores, and risk ratings were associated with the participant's style. Martinsons \& Davison (2007) examined information systems issues that exist due to the distinctively American, Japanese and Chinese styles of strategic decision making [7]. The existence of international differences in analyzing and conceptualizing strategic decisions highlights the need for more research on the global applicability of Information Systems such as decision support systems and executive information systems [5].

\subsection{ICT Impact Assessment}


To assess ICT impact, we utilize Canter (1996)'s Environmental Impact Assessment [8] and Wijnhoven and Wassenaar (1990)'s IT Impacts research [9]. Canter developed this assessment process to evaluate environmental impacts. We adapt it to explore ICT impacts. Canter (1996) posits impacts resulting from proposed actions can be considered in one or more of the following categories [8]:

- Beneficial or detrimental

- Naturally reversible or irreversible

- Reparable via management practices or irreparable

- Short term or long term

- Temporary or continuous

- Construction or operational phase

- Local, regional, national, or global

- Accidental or Planned (recognized beforehand)

- Direct or Primary, or Indirect or secondary

- Cumulative or Single

Canter (1996) states [8]:

Direct effects are caused by the action and occur at the same time and place. Indirect effects are caused by the action and occur later or farther removed in distance, but are still reasonably foreseeable. Indirect effects may include growth-inducing effects and other effects related to induced changes in the pattern of land use, population density or growth rate, and related effects on air and water and other natural systems, including ecosystems. Effects include ecological (such as the effects on natural resources and on the components, structures, and functioning of affected ecosystems), aesthetic, historic, cultural, economic, social, or health, whether direct, indirect, or cumulative. Effects also include those resulting from actions which may have both beneficial and detrimental effects, even if on balance the agency believes that the effect will be beneficial. Cumulative impact: The impact on the environment which results from the incremental impact of the action when added to other past, present, and reasonably foreseeable future actions regardless of what agency (federal or nonfederal) or person undertakes such other actions. Cumulative impacts can result from individually minor, but collectively significant, actions taking place over a period of time.
These effects are typically evaluated using interaction matrices: a presentation of project activities along one axis, with appropriate environmental factors listed along the other axis of the matrix. To use the matrix evaluators need to the potential impacts, either beneficial or detrimental, of each project action relative to each environmental factor. To support this analysis, Canter (1996) proposes the following the codes [8]:

SB: Significant beneficial impact (represents a highly desirable outcome in terms of either improving the existing quality of the environmental factor or enhancing that factor from an environmental perspective) SA: Significant adverse impact (represents a highly undesirable outcome in terms of either degrading the existing quality of the environmental factor or disrupting that factor from an environmental perspective) B: Beneficial impact (represents a positive outcome in terms of either improving the existing quality of the environmental factor or enhancing that factor from an environmental perspective)

A: Adverse impact (represents a negative outcome in terms of either degrading the existing quality of the environmental factor or disrupting that factor from an environmental perspective)

b: Small beneficial impact (represents a minor improvement in the existing quality of the environmental factor or a minor enhancement in that factor from an environmental perspective) a: Small adverse impact (represents a minor degradation in the existing quality of the environmental factor or a minor disruption in that factor from an environmental perspective) $\boldsymbol{O}$ : No measurable impact is expected to occur as a result of considering the project action relative to the environmental factor M: Some type of mitigation measure can be used to reduce or avoid a small adverse, adverse, or significant adverse impact NA: The environmental factor is not applicable or relevant for the proposed project

With regards to IT, we utilize Wijnhoven and Wassenaar (1990)'s list of twelve information technology impacts in organizations [9]. The list includes:

1. Departmentalization

2. Hierarchy 
3. Span of control

4. Functional differentiation

5. Delegation of decision-making authority

6. Evaluation

7. Formalization

8. Power

9. Lateral relations

10. Stability and rigidity

11. Job routinization

12. Institutionalization

We utilize the aforementioned literature to propose two ICT4D solution artifacts. Artifact A is a general framework that integrates culture, decision styles and IT impact. Artifact B is an application of a simple matrix that juxtaposes the role cultural dimensions and decision styles in China. For each artifact we propose a 2-phase process to enable IT managers and national leaders conduct a thorough ICT4D assessment.

\section{ICT4D Solution Artifact A - Culture, Decision Making, and IT Impact}

\subsection{Description of the Procedure to Assess Culture and Decision Making}

\subsubsection{Phase 1: Provide Standard Risk Estimates}

1. Identify Relevant Impact Factors

2. Identify Focus Area (e.g. Security)

3. Select Group of Competent Evaluators

4. The Evaluation Group provides a Risk Rating for each dimension of the Focus Area (e.g. Confidentiality, Integrity, Availability) with respect to the levels of the ICT Impact Factor \& the levels of the Cultural Dimension.

\subsubsection{Phase 2: Provide Standard Risk Estimates}

1. Estimate level of each ICT Impact Factor that applies to the local context.

2. Estimate level of each Cultural Dimension that applies to the local context.

3. Given the relevant levels of the ICT Impact Factors \& the Cultural Dimensions, use the Risk Estimates table that was developed in Phase 1 to estimate the corresponding Risk Levels of the Focus Area (e.g. Security) for each ICT Impact Factor \& Cultural Dimension that apply to the local context.

\subsection{A Simple Illustration of the Artifact A}

Table 2: Solution Artifact A

\begin{tabular}{|c|c|c|c|c|}
\hline $\begin{array}{l}\text { Levels of } \\
\text { ICT Impact Factor }\end{array}$ & $\begin{array}{l}\text { Cultural } \\
\text { Dimension }\end{array}$ & $\begin{array}{l}\text { Focus } \\
\text { Dimensions }\end{array}$ & $\begin{array}{l}\text { Risk } \\
\text { Rating }\end{array}$ & Rationale \\
\hline \multirow[t]{3}{*}{$\begin{array}{l}\text { Departmentalization: } \\
\text { Functional } \\
\text { (functional departmentalization } \\
\text { schemes worked best in a } \\
\text { predictable environment ... aim to } \\
\text { achieve the outcomes of accuracy } \\
\text { and efficiency, but discount speed } \\
\text { and flexibility in the process ... tend } \\
\text { to centralize decision-making) }\end{array}$} & \multirow[t]{3}{*}{$\begin{array}{l}\text { Uncertainty } \\
\text { Avoidance: } \\
\text { Strong }\end{array}$} & \multirow[t]{2}{*}{ Confidentiality } & $\begin{array}{l}\mathbf{B} \text { if } \\
\text { Conf is } \\
\text { High }\end{array}$ & $\begin{array}{l}\text { Despite the assumption of a } \\
\text { predictable environment \& } \\
\text { the objective of Accuracy, } \\
\text { because of the High } \\
\text { Uncertainty Avoidance there } \\
\text { may be the perception that } \\
\text { Confidentiality is more } \\
\text { important than it actually is. }\end{array}$ \\
\hline & & & $\begin{array}{l}\text { A if } \\
\text { Conf is } \\
\text { Low }\end{array}$ & \\
\hline & & Integrity & $\begin{array}{l}\text { SB if } \\
\text { Int is } \\
\text { High }\end{array}$ & $\begin{array}{l}\text { Despite the assumption of a } \\
\text { predictable environment \& } \\
\text { the objective of Accuracy, } \\
\text { because of the High } \\
\text { Uncertainty Avoidance there } \\
\text { may be the perception that } \\
\text { Integrity is more Beneficial } \\
\text { than it actually is. }\end{array}$ \\
\hline
\end{tabular}




\begin{tabular}{|c|c|c|c|c|}
\hline & & & $\begin{array}{l}\text { SA if } \\
\text { Int is } \\
\text { Low }\end{array}$ & \\
\hline & & Availability & $\begin{array}{l}\mathbf{B} \text { if } \\
\text { Avail is } \\
\text { High }\end{array}$ & \\
\hline & & & $\begin{array}{l}\text { A if } \\
\text { Avail is } \\
\text { Low }\end{array}$ & \\
\hline & $\begin{array}{l}\text { Uncertainty } \\
\text { Avoidance: } \\
\text { Weak }\end{array}$ & Confidentiality & $\begin{array}{l}\mathbf{b} \text { if } \\
\text { Conf is } \\
\text { High }\end{array}$ & \\
\hline & & & $\begin{array}{l}\text { a if } \\
\text { Conf is } \\
\text { Low }\end{array}$ & \\
\hline & & Integrity & $\begin{array}{l}\mathbf{b} \text { if } \mathbf{I n t} \\
\text { is High }\end{array}$ & \\
\hline & & & $\begin{array}{l}\text { a if } \mathbf{I n t} \\
\text { is Low }\end{array}$ & \\
\hline & & Availability & $\begin{array}{l}\text { b if } \\
\text { Avail is } \\
\text { High }\end{array}$ & $\begin{array}{l}\text { Assuming a predictable } \\
\text { environment, and given Weak } \\
\text { Uncertainty Avoidance then } \\
\text { High Data Availability would } \\
\text { not be considered to provide } \\
\text { exceptional Benefit }\end{array}$ \\
\hline & & & $\begin{array}{l}\text { a if } \\
\text { Avail is } \\
\text { Low }\end{array}$ & \\
\hline $\begin{array}{l}\text { Departmentalization: } \\
\text { Divisional } \\
\text { (Divisional departmentalization }\end{array}$ & $\begin{array}{l}\text { Uncertainty } \\
\text { Avoidance: } \\
\text { Strong }\end{array}$ & Confidentiality & $\begin{array}{l}\text { SB if } \\
\text { Conf is } \\
\text { High }\end{array}$ & \\
\hline $\begin{array}{l}\text { environment .. place the emphasis on } \\
\text { speed and flexibility, while de- } \\
\text { emphasizing accuracy and }\end{array}$ & & & $\begin{array}{l}\text { SA if } \\
\text { Conf is } \\
\text { Low }\end{array}$ & \\
\hline & & Integrity & $\begin{array}{l}\text { SB if } \\
\text { Int is } \\
\text { High }\end{array}$ & $\begin{array}{l}\text { Assuming a random } \\
\text { environment though there is } \\
\text { more emphasis on Flexibility } \\
\text { than Accuracy, and given } \\
\text { Strong Uncertainty } \\
\text { Avoidance then High Data } \\
\text { Integrity would be }\end{array}$ \\
\hline
\end{tabular}




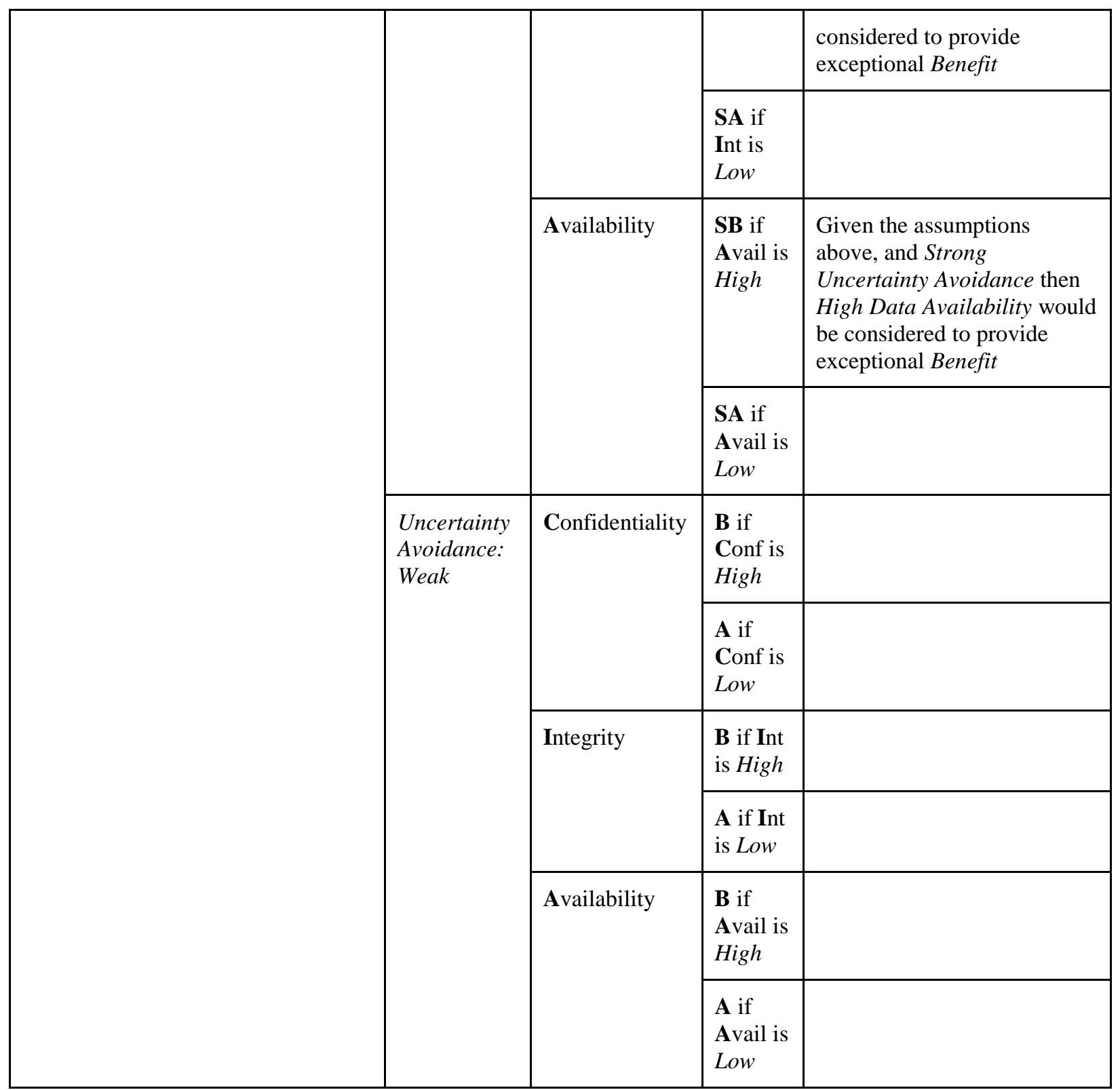

\section{ICT4D Solution Artifact B - Culture and Decision Making}

\subsection{Description of the Procedure to Assess Culture and Decision Making}

\subsubsection{Phase 1: Provide Standard Risk Estimates}

1. Identify Cultural Dimension for the Country of Interest

2. Identify Impact of Decision Styles on the Cultural Dimensions
3. Select a Group of Competent Evaluators

4. Instruct the Evaluation Group to provide a Risk Rating (low, medium, high) for each dimension of the Focus Area (e.g. Confidentiality, Integrity, Availability) with respect to the Decision Styles \& the Cultural Dimension.

\subsubsection{Phase 2: Application - Local Context}

1. Estimate the level of each ICT Impact Factor that applies to the local context.

2. Estimate the level of each Cultural Dimension that applies to the local context. 
3. Given the relevant levels of the ICT Impact Factors \& the Cultural Dimensions, use the Risk Estimates table that was developed in Phase 1 to estimate the corresponding Risk Levels of the Focus Area (e.g. Security) for each ICT Impact Factor \& Cultural Dimension that apply to the local context.

\subsection{An application of the procedure: Evaluating CIA Risk in China}

The following figure provides an example of the use of Artifact B to provide a high-level evaluation of the cultural dimensions and CIA security risk associated with ICT in China.

Table 3. Solution Artifact B

\begin{tabular}{|c|c|c|c|c|}
\hline & \multicolumn{4}{|c|}{ Systems Development Life Cycle } \\
\hline Decision Style & Analytical & Directive & Conceptual & Behavioral \\
\hline \multicolumn{5}{|l|}{$\begin{array}{l}\text { Cultural } \\
\text { Dimension }\end{array}$} \\
\hline $\begin{array}{l}\text { Individualism } \\
\text { (Low) } \\
\text { Collectivist } \\
\text { approach - } \\
\text { Focus on } \\
\text { what's best for } \\
\text { the group } \\
\text { (company) }\end{array}$ & $\begin{array}{l}\text { CIA Risk Low } \\
\text { (emphasis on } \\
\text { planning, forecasting, } \\
\text { and identifying } \\
\text { what's in the best } \\
\text { interest of the group) }\end{array}$ & $\begin{array}{l}\text { CIA Risk Medium } \\
\text { (systematic focus } \\
\text { may minimize the } \\
\text { discovery of new } \\
\text { solutions) }\end{array}$ & $\begin{array}{l}\text { CIA Risk Medium } \\
\text { (exploring new } \\
\text { options with the } \\
\text { group's best interest } \\
\text { in mind may result in } \\
\text { timely and effective } \\
\text { solutions, however, } \\
\text { taking risks may } \\
\text { result in negative } \\
\text { impacts) }\end{array}$ & $\begin{array}{l}\text { CIA Risk Medium } \\
\text { (solve problem } \\
\text { through people is } \\
\text { both promising and } \\
\text { challenging...people } \\
\text { represent the biggest } \\
\text { threat and } \\
\text { opportunity to CIA) }\end{array}$ \\
\hline $\begin{array}{l}\text { Power } \\
\text { Distance } \\
\text { (Large) }\end{array}$ & $\begin{array}{l}\text { CIA Risk Medium } \\
\text { (top-down structure } \\
\text { may } \\
\text { discourage/prevent } \\
\text { creative and effective } \\
\text { solutions) }\end{array}$ & $\begin{array}{l}\text { CIA Risk Medium } \\
\text { (systematic focus and } \\
\text { top-down structure } \\
\text { may encourage } \\
\text { employees to do the } \\
\text { wrong things well) }\end{array}$ & $\begin{array}{l}\text { CIA Risk Medium } \\
\text { (a top-down structure } \\
\text { may make it difficult } \\
\text { for team members to } \\
\text { exert creativity and } \\
\text { risk-taking behavior) }\end{array}$ & $\begin{array}{l}\text { CIA Risk Medium } \\
\text { (solve problem } \\
\text { through people is } \\
\text { both promising and } \\
\text { challenging...people } \\
\text { represent the biggest } \\
\text { threat and } \\
\text { opportunity to CIA) }\end{array}$ \\
\hline $\begin{array}{l}\text { Uncertainty } \\
\text { Avoidance } \\
\text { (Weak) }\end{array}$ & $\begin{array}{l}\text { CIA Risk Medium } \\
\text { (flexibility may result } \\
\text { in agile solutions) }\end{array}$ & $\begin{array}{l}\text { CIA Risk Low } \\
\text { (a systematic process } \\
\text { coupled with flexible } \\
\text { rules, may be an ideal } \\
\text { combination for } \\
\text { identifying and } \\
\text { implementing } \\
\text { effective CIA } \\
\text { solutions) }\end{array}$ & $\begin{array}{l}\text { CIA Risk Medium } \\
\text { (exploring new } \\
\text { options with flexible } \\
\text { rules may result in } \\
\text { timely and effective } \\
\text { solutions, however, } \\
\text { taking risks may } \\
\text { result in negative } \\
\text { impacts) }\end{array}$ & $\begin{array}{l}\text { CIA Risk Medium } \\
\text { (solve problem } \\
\text { through people is } \\
\text { both promising and } \\
\text { challenging...people } \\
\text { represent the biggest } \\
\text { threat and } \\
\text { opportunity to CIA) }\end{array}$ \\
\hline $\begin{array}{l}\text { Masculinity } \\
\text { (High) }\end{array}$ & $\begin{array}{l}\text { CIA Risk Medium } \\
\text { (Limited contribution } \\
\text { from some team }\end{array}$ & $\begin{array}{l}\text { CIA Risk Medium } \\
\text { (Limited contribution } \\
\text { from some team }\end{array}$ & $\begin{array}{l}\text { CIA Risk Medium } \\
\text { (Limited contribution } \\
\text { from some team }\end{array}$ & $\begin{array}{l}\text { CIA Risk Medium } \\
\text { (Limited contribution } \\
\text { from some team }\end{array}$ \\
\hline
\end{tabular}




\begin{tabular}{|c|c|c|c|c|}
\hline $\begin{array}{l}\text { Half of society } \\
\text { doesn't fully } \\
\text { participate in } \\
\text { the problem } \\
\text { solving/idea } \\
\text { generation }\end{array}$ & $\begin{array}{l}\text { members may result } \\
\text { in few } \\
\text { alternatives/solutions) }\end{array}$ & $\begin{array}{l}\text { members may result } \\
\text { in few } \\
\text { alternatives/solutions) }\end{array}$ & $\begin{array}{l}\text { members may result } \\
\text { in few } \\
\text { alternatives/solutions) }\end{array}$ & $\begin{array}{l}\text { members may result } \\
\text { in few } \\
\text { alternatives/solutions) }\end{array}$ \\
\hline
\end{tabular}

\section{Discussion}

The proposed solution artifacts will enable IT managers and public officials in developing countries to assess the risks associated with adopting technological innovations. Future research is needed to address the plethora of ethical and societal challenges associated with ICT4D. There are many questions that need to be answered. Are individual rights compromised by the large volume of data available on social media (held by private companies and sold to intelligence agencies and other companies)? How can nations protect citizens without suffocating the private enterprise? Do citizens have a right to privacy? Some citizens haven't volunteered to give it up (asymmetric power, asymmetric information, agency, citizen-rights).

This paper provides assessment framework artifacts that are grounded in extant research on culture, decision-making and ICT impacts. The intricate nature of ICT4D evaluation highlights the need for an international consortium to evaluate ICT4D issues and provide recommendations to leaders in developing nations.

\section{Conclusion}

The proposed procedures will be beneficial for government sponsored organizations. It provides a systematic, guiding framework for government agencies and supporting organizations to evaluate their IT resources, risk and impact. The proposed assessment framework artifacts highlight the importance of public-private partnerships. The working group in phase one would include representatives from both public and private organizations. In this paper, we present a assessment framework to help both developed and developing nations assess ICT Impact. This resource will be especially useful to developing countries where the knowledge and skills necessary to effectively assess ICT impact and risk may not be available, especially in small island developing states. Future research is needed to test and validate the proposed procedure. This paper provides a conceptual framework for future research on ICT impacts, cultural dimensions and decision making styles.

\section{References}

[1]Osei-Bryson, K.and Vogel, D. (nd). The Journal of Information Technology for The Journal of Information Technology for Development Call for Papers: Special Issue Cyber-Security for Development. Retrieved on April 2, 2016. Accessed from:

https://mailman.stanford.edu/pipermail/liberationtech/attac hments/20120713/3de956c0/attachment.pdf Rowe, A. J., \&

[2]Hofstede, G. (1983). The cultural relativity of organizational practices and theories. Journal of international business studies, 14(2) 75-89.

[3]Boulgarides, J. D. (1983). Decision styles-A perspective. Leadership \& Organization Development Journal, 4(4), 3-9.

[4]Rowe, A. J., \& Mason, R. O. (1987). Managing with style: A guide to understanding, assessing, and improving decision making. Jossey-Bass.

[5] Osei-Bryson, K. M., \& Barclay, C. (2015). Strategic Project Management: Contemporary Issues and Strategies for Developing Economies.

[6]Nutt, P. C., \& Backoff, R. W. (1993). Transforming public organizations with strategic management and strategic leadership. Journal of Management, 19(2), 299347.

[7]Martinsons, M. G., \& Davison, R. M. (2007). Strategic decision making and support systems: Comparing American, Japanese and Chinese management. Decision Support Systems, 43(1), 284-300.

[8]Canter, L. W., (1996). Environmental impact assessment. Accessed on May 1, 2016. Retrieved from $\mathrm{ftp} / / /$ www.energia.bme.hu/pub/hullgazd/Environmental\%2 0Engineers'\%20Handbook/Ch02.pdf

[9] Wijnhoven, A. B. J. M., \& Wassenaar, D. A. (1990). Impact of information technology on organizations: The state of the art. International Journal of Information Management, 10(1), 35-53. 